Original Research Paper

\title{
The Effect of Zinc-Biocomplex and Vitamin E Supplementation on Local Kacang Goats Semen
}

\author{
${ }^{1}$ Tintin Rostini, ${ }^{1}$ Irwan Zakir and ${ }^{2}$ Danang Biyatmoko \\ ${ }^{1}$ Departement of Animal Science, Faculty of Agriculture, Universitas Islam Kalimantan, \\ Banjarmasin- South Kalimantan, Indonesia \\ ${ }^{2}$ Departement of Animal Science, Faculty of Agriculture, Lambung Mangkurat University, \\ Banjarmasin- South Kalimantan, Indonesia
}

\begin{abstract}
Article history
Received: 14-04-2020

Revised: 02-06-2020

Accepted: 20-06-2020

Corresponding Author:

Tintin Rostini

Departement of Animal

Science, Faculty of

Agriculture, Universitas Islam

Kalimantan, Banjarmasin-

South Kalimantan, Indonesia

Email: tintin_rostini@yahoo.com
\end{abstract}

\begin{abstract}
This study was aimed at determining the effect of zincbiocomplex and vitamin E supplementation on the quality of on local Kacang goats semen. Sixteen Kacang goats (males) aged 12-13 months with an average body weight of $13 \pm 1.2 \mathrm{~kg}$ were used. The experimental design used was a Completely Randomized Design (CRD) consisting of four replications. Artificial vagina was used to collect semen from 16 Male goats. The feed provided consisted of local forages (king grass, bengala grass, legumes) plus a mixture of reinforcing feed with a crude protein content of $14 \%$. The observed macroscopic semen, characteristics were semen, volume, $\mathrm{pH}$, color. odor and consistency. Moreover. Microscopic semen characteristics observed were spermatozoa motility, Viability membrane integrity and abnormality spermatozoa. In conclusiont supplementation of zinc-biocomplek and vitamin $\mathrm{E}$ has the potential to improve the quality of Spermatozoa.
\end{abstract}

Keywords: Goat, Vitamin, Supplementation, Spermatozoa

\section{Introduction}

One of the factors affecting the quality of semen is the provision of rations with proper and good nutritional value. The nutrient essential elements that must be added to the ration to improve reproduction are vitamin $\mathrm{E}$ and Zinc mineral. Bhardwai et al. (2018) state, that vitamin $\mathrm{E}$ is essential for reproduction. When being used routinely as a supplement, vitamin $\mathrm{E}$ can increase growth and maintain zygote development. Vitamin $\mathrm{E}$ is able to prevent damage to spermatozoa in male cattle and maintain the development of zygotes in female cattle. In the process of spermatogenesis, vitamin E functions as an antioxidant that is able to neutralize free radicals resulting from aerobic metabolism (Ogbuewu et al., 2010). The $\mathrm{Zn}$ mineral (zinc) is involved in several enzymatic reactions related to carbohydrate metabolism, protein synthesis and nucleic acid metabolism (Smith and Akinbamijo, 2000). Zinc influences the process of spermatogenesis (Wong et al., 2002; Ebisch et al., 2003), control of sperm motility (Wroblewski et al., 2003) and stabilization of sperm membranes (Kendall et al., 2000). Therefore zinc is very important for active growth and division of gonadal cells, so that the reproductive function will be disrupted if zinc mineral deficiency.
There have been many studies about the form and way of serving supplementary feeds, such as mineral blocks, urea, vitamins, molasses and others. However, this effort has not given maximum results or improving the quality of feed ingredients to the cattle in both male and female, because it is given in a single form so that easily hydrogenated in the rumen and does not reach the desired target organ. It It is therefore necessary to find a supplementation solution for the combination of minerals and vitamins to reach the target organ. One alternative is the administration of combined zinc mineral and vitamin $\mathrm{E}$.

Zinc mineral is an important factor in the functional immune system and improve metabolic processes in the body. This is possible because zinc plays a role as a multienzyme cofactor that is active in the metabolism of carbohydrates, proteins, fats and nucleic acids (NRC, 2007). However, the absorption rate of zinc is low without the help of other components such as vitamins, especially vitamin Inonie et al. (2016), states, that vitamin $\mathrm{E}$ is a natural antioxidant, which acts as maintaining optimal performance, normal growth and with zinc maintaining immune function. Vitamin $\mathrm{E}$ can also prevent damage to components of unsaturated fatty acids due to free radicals and changes due to pollutants originating in the environment. 
Therefore, this research aimed to determine the effect of combining zinc-biocomplex and vitamin $\mathrm{E}$ to improve the quality of spermatozoa of local kacang goat.

\section{Materials and Methods}

The subjects of this study were 16 male goats. The male goats aged 12-13 months with average body weight ranging from $13 \pm 1.2 \mathrm{~kg}$ (with the coefficient of diversity $16.50 \%$ ). Each goat is provided by a female angler (teaser). The tool used to store semen is an artificial vagina or Artificial Vagina (AV) given vaseline for artificial vaginal lubricant and hot water with a temperature of $\pm 45^{\circ} \mathrm{C}$ which is inserted into the artificial vagina so that the atmosphere can resemble a real vagina. The treatment of feeding the material with and without supplementation in goats consists of: (TR1), local forages-concentrations of $14 \%$ PK without supplementation of zinc and vitamin E. (TR2), TR1+ supplementation $+60 \mathrm{mg}$ zinc/kg as zinc-biocomplex and 1 capsule (22 IU) of vitamin E. (TR3,) TR1 +120 mg zinc/kg as zinc-biocomplex +1 capsule ( $22 \mathrm{IU})$ of vitamin $\mathrm{E}$ and (TR4), TR1 +180 $\mathrm{mg}$ zinc/kg as zinc-biocomplex +1 capsule (22 1U) of vitamin E. Feed plus zinc biocomplek and vitamin $\mathrm{E}$ all mixed according to treatment (Table 1).

The variables observed were the evaluation of spermatozoa characteristics evaluated in both macroscopic and microscopic term of observation, including several parameters which are volume, odor, color, consistency, motility, viability, spermatozoa membrane integrity, spermatozoa abnormality (with negosin and eosin coloring) and storability of spermatozoa to the percentage of motility and viability during $0,2,4,6,8$ to $24 \mathrm{~h}$.

\section{Spermatozoa Motility Assessment}

Spermatozoa motility is determined by placing one drop of spermatozoa that have been diluted with $0.9 \%$ $\mathrm{NaCl}$ solution on glass objects and covered with glass covers. Observation of progressive moving spermatozoa was carried out subjectively on six different fields of view under a microscope with $400 \times$ magnification. Assessments werebased on the following $0 \%$ (no forward movement of the spermatozoa) to $100 \%$ (all spermatozoa).

\section{Spermatozoa Viability Assessment}

Determination of the percentage of viability of spermatozoa was carried out using the eosin-negrosin coloring method with the composition of the eosinnegrosin coloring agent for $300 \mathrm{~mL}$ of mili-Q water consisting of 3.3 grams of yellow eosin (Wako Pure Chemical Industries, 058-00062), 20 grams of nigrosin (Sigma - Aldrich, 198285) and 1.5 g sodium citrate. A total of $10 \mu \mathrm{L}$ of semen sample and $40 \mu \mathrm{L}$ of eosinnegrosin were mixed on a glass object and dried using a spirits lamp for $15 \mathrm{sec}$ before observing under a microscope at $400 \times$ magnification. Spermatozoa that are categorized as living are spermatozoa that does not absorb color in their heads (spermatozoa that are not colored), where as spermatozoa that are categorized as dead are spermatozoa that absorb color so that the head will turn red. The percentage of spermatozoa viability is determined based on a comparison between the number of live spermatozoa and the total number of spermatozoa.

\section{Spermatozoa Membrane Integrity Assessment}

Spermatozoa membrane integrity assessment was examined using a hypoosmotic swelling test (HOS-test) with the composition of HOS solution for $10 \mathrm{~mL}$ mili-Q water plus $0.135 \mathrm{~g}$ fructose (Merck, Germany) and $0.0735 \mathrm{~g}$ trisodium citrate $2 \mathrm{H}_{2} \mathrm{O}$. The semen samples of $20 \mu \mathrm{L}$ were diluted with $80 \mu \mathrm{L}$ of HOS solution and left for $10 \mathrm{~min}$ at room temperature. For the purposes of observation, $10 \mu \mathrm{L}$ of semen sample is dropped on a glass object covered with a glass cover and evaluation is carried out under a microscope at 400× magnification. Calculations at this stage of study were performed on five random fields of view of spermatozoa that have a circular tail (intact plasma membrane) or a straight tail (plasma membrane is not intact) (Jeyendran et al., 1984).

Table 1: The nutrients of feeding supplemented by zinc-biocomplex and vitamin E

\begin{tabular}{llllllll}
\hline Nutrients & TR1 & TR2 & TR3 & TR4 & RSD & SEM & Significant level \\
\hline Dry matter (\%) & 93,14 & 93,07 & 94,42 & 94,46 & 0,77 & 0,39 & NS \\
Organic matter (\%) & 84,54 & 85,62 & 86,81 & 88,27 & 1,60 & 0,801 & NS \\
Crude protein (\%) & 12,86 & 13,11 & 13,38 & 13,67 & 0,35 & 0,174 & NS \\
Fat (\%) & 3,75 & 4,2 & 4,43 & 4 & 0,29 & 0,145 & NS \\
Crude fiber (\%) & 27,32 & 27,63 & 26,93 & 27,74 & 0,36 & 0,182 & NS \\
Ca $(\%)$ & 0,68 & 0,6 & 0,84 & 0,91 & 0,14 & 0,071 & NS \\
P $(\%)$ & 0,36 & 0,43 & 0,26 & 0,26 & 0,08 & 0,042 & NS \\
\hline
\end{tabular}

Information: (TR1) Local forage-concentrated without supplementation of zinc-biocomplex and vitamin $\mathrm{E}$

(TR2) TRl + supplementation + $60 \mathrm{mg}$ zinc lkg as zinc-biocomplex and vitamin $\mathrm{E}$

(TR3) TR1 + supplementation $120 \mathrm{mg}$ zinc $\mathrm{lkg}$ as zinc-biocomplex and vitamin E

(TR4) TR1 + supplementation $180 \mathrm{mg}$ zinc lkg as zinc-biocomplex and vitamin E

$\mathrm{SEM}=$ Standar Error of the Means, RSD = Residuals Standard Deviation

$\mathrm{NS}=$ No significant correlation, $*=P<0,05$ 


\section{Spermatozoa Abnormality Assessment}

Spermatozoa abnormality assessment, namely secondary spermatozoa (broken normal head and bent tail) that occur during the storage process or cryopreservation of spermatozoa were observed using a $400 \times$ magnification microscope. The total number of spermatozoa counted was 200 spermatozoa (Ridwan, 2009)

\section{Data Analysis}

Data obtained for the quality inspection of spermatozoa were analyzed using analysis of variance and continued with the Least Significant Difference test (LSD).

\section{Results and Discussion}

The quality of spermatozoa is based on macroscopic and microscopic observations. For instance, in Table 2, there was significant difference $(P<0.05)$ between treatments in the average volume of spermatozoa produced. Furthermore, the volume of semen produced was $0.74-1.20 \mathrm{~mL}$, which was $0.20 \mathrm{~mL}$ higher than the research carried out by Kusumawati et al. (2017), on the spermatozoa of Kacang goats. In this study, the spermatozoa were fed with zinc biocomplex supplementation and vitamin $\mathrm{E}$ to influence the formation process and increase its volume. This is in line with the researches carried out by (Wong et al., 2002; Ebisch et al., 2003) where zinc increased the process of spermatogenesis, while Hidayati (2017), stated that the volume of each ejaculation is influenced by feed, age, frequency of storage, etc. According to Kusumawati et al. (2016), the volume of goat semen during every ejaculation ranges from 0.5 to $1.5 \mathrm{~mL}$, depending on feed and environmental conditions.

However, the degree of acidity $(\mathrm{pH})$ of spermatozoa in this study ranged from 6.48 to 6.73 , therefore, the overall $\mathrm{pH}$ of the semen from Kacang goat is in the normal range. These results are similar to the research carried out by Susilawati (2011) which stated that the $\mathrm{pH}$ of spermatozoa in goats is 6.4 to 6.8 , while Kartasudjana (2001) reported that it generally has a $\mathrm{pH}$ ranging from 5.9-7.0. Hastono and Herawati (2013) stated that the normal $\mathrm{pH}$ of 5.9-7.3. $\mathrm{pH}$ is a limiting factor for the survival of spermatozoa in semen, where a pH lower than 6 leads to the accumulation of lactic acid from anaerobic metabolism with the ability to reduce the level of motility and viability of spermatozoa (Ridwan, 2009).

Semen's color is often related to its thickness and fades, with a decrease in concentration (Zubair, 2017). The color produced in this study is cream and insignificantly different between treatments $(P<0.05)$, which shows that the goat semen has good quality, with a clear cream color and a good level of consistency. This is in line with Pamungkas and Anwar (2014), study, which stated that the cream color shows good quality of spermatozoa and when the concentration decreases, the semen turns thinner and fades. In the good semen, the degree of viscosity is similar or slightly thicker than milk, while in the bad semen, both color and thickness have the same qualities as coconut water.

Spermatozoa motility is defined as its movement from one place to another. In this study, it showed significant differences between treatments $(P<0.05)$, where TR3 was the highest at $81.46 \%$ and TR1, the lowest at $73.03 \%$. It is suspected that zinc biocomplex supplementation and vitamin $\mathrm{E}$ in feed possess a significant effect on the motility of goat spermatozoa. According to (Susilawati, 2011). Spermatozoa motility above $70 \%$ has a higher survival rate compared to those below this range (Anerao et al., 2010). Stated that this survival rate is one of the biological characteristics of spermatozoa. One of the relevant indicators in determining its quality is carried out both in vivo and in vitro (Elzananty and Malm, 2007). Motility is the progressive potential of spermatozoa and it is needed when the female reproductive tract tries to reach its destination. The motility produced in this study is higher because of the combination of zinc biocomplex and vitamin $\mathrm{E}$, which helps in the spermatozoa maturation process and causes an increase of the androgen levels in blood plasma and spermatogenesis activity. This is in line with the research carried out by Smith and Akinbamijo (2000), which stated that zinc minerals influence the energy synthesis process for the development of spermatozoa motility. Meanwhile, according to Wroblewski et al. (2003), minerals and vitamins are controls in sperm motility.

The spermatozoa viability produced was significantly different $(P<0.05)$. Show an increase in the percentage of sustainability with the addition of zinc biocomplex and vitamin $\mathrm{E}$ in the feed from $78.62-81.76 \%$. This shows that this addition increases the viability correlated in raising the fertility of spermatozoa. This is similar to the research conducted by (Simmon and Fitzpatrick, 2012). where the spermatozoa viability linear with the success of fertilization is influenced by the nutritional intake of feed consumed by livestock.

The quality of spermatozoa in the Kacang goat is determined by the percentage of motility, viability and concentration rate. The results based on Fig. 1 show that the highest viability was seen in TR3 treatment and the lowest in TR1. This shows that the provision of zinc biocomplex and vitamin $\mathrm{E}$ of $120 \mathrm{mg} / \mathrm{head} /$ day in feed induces an increase in spermatozoa viability. These minerals have a significant effect $(P<0.05)$ on the spermatozoa concentration of the Kacang goat, as shown in Table 3. The simultaneous addition of vitamin $\mathrm{E}$ and zinc minerals is able to provide the greatest effect in increasing the concentration of spermatozoa. According to Lodhi et al. (2008), vitamin E maintains the fatty acids needed in the 
formation of prostaglandins, which are mediators of the gonadotropin hormone. Mean while, the zinc mineral acts as an antioxidant and protects the body from lipid peroxidase attacks (Smith and Akinbamijo, 2000).

The administration of this mineral did not show a significant effect $(P<0.05)$ on the percentage of live spermatozoa of the Kacang goat, as produced in Table 3 However, giving zinc as much of $120 \mathrm{mg} / \mathrm{kg}$ tends to neutralize the free radicals in the livestock body, thereby increasing the number of spermatozoa. In contrast, the provision of $180 \mathrm{mg} / \mathrm{kg}$ led to a decrease like TR4. It is suspected that livestock does not have the ability to metabolize high minerals, thereby reducing the percentage of spermatozoa. This is in line with the research carried out by Suharyati and Hartono (2013) which stated that the use of Vitamin E and minerals as non-enzymatic antioxidants capable of neutralizing free radicals, tends to increase the number of live spermatozoa, in limited amounts.

The highest spermatozoa abnormalities were seen in TR1 treatment and the lowest in TR3. This shows that the provision of $\mathrm{Zn}$ biocomplex at $120 \mathrm{mg} / \mathrm{kg}$ and vitamin $\mathrm{E}$ tends to reduce spermatozoa abnormalities when compared with other treatments, although this is not significantly different $(P<0.05)$. However, it is still within a reasonable limit of less than $5 \%$, therefore, the Kacang goat is classified fertile. According to Salomon and Maxwell (2000), spermatozoa abnormalities of fertile goats and sheep need to be more than $15 \%$ of abnormal sperm. This creates interference in the fertilization process (Dorado et al., 2007). A high percentage of spermatozoa abnormalities prevent it from reaching the egg or fertilization (Chenoweth, 2005).

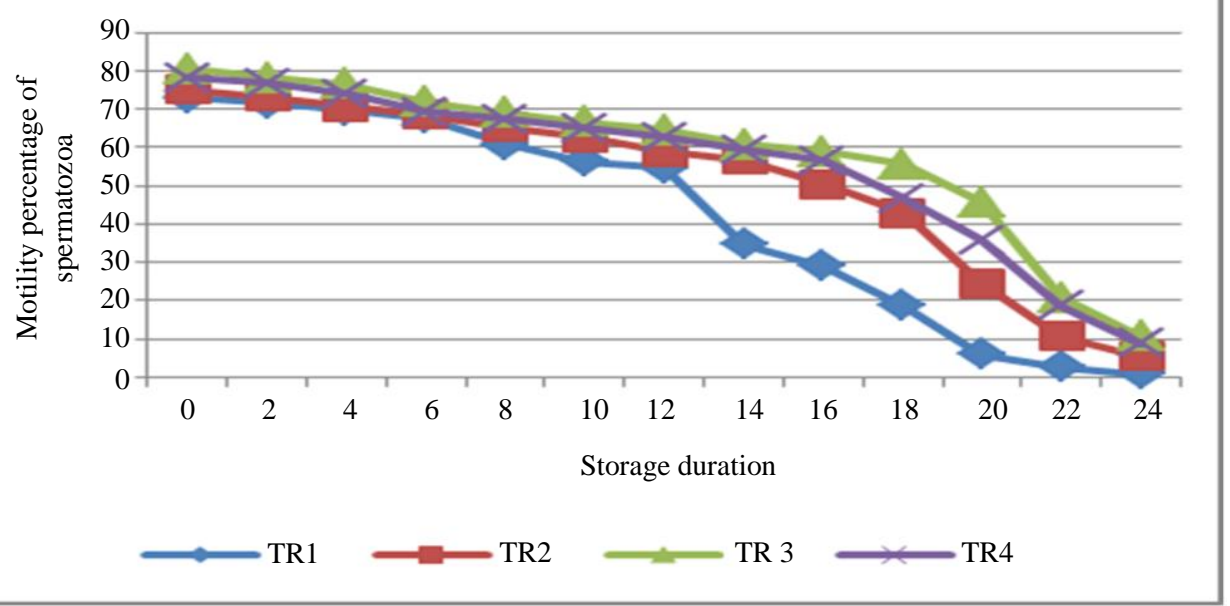

(a)

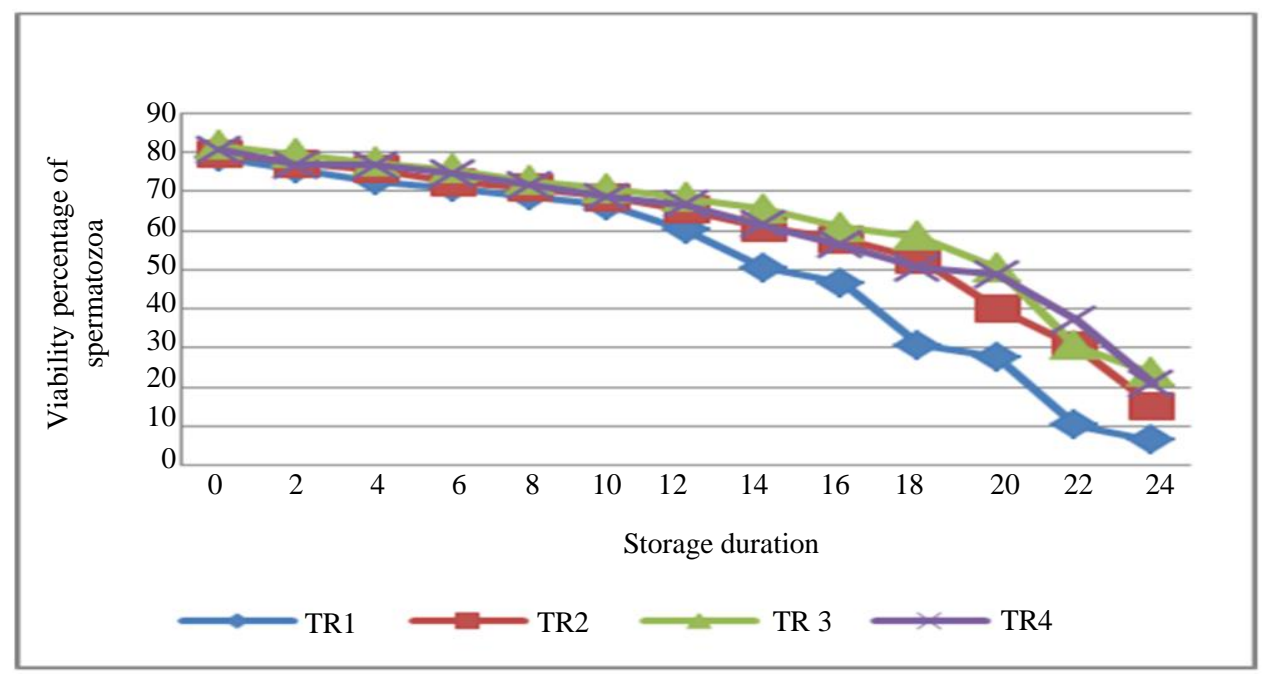

(b)

Fig. 1: (a) Storage duration to influence spermatozoa motility, (b) Storage duration to influence spermatozoa viability 
Table 2: Macroscopic characteristics of local kacang goat fresh semen with certain feeding of zinc-bicomplex and vitamin E supplementation

\begin{tabular}{|c|c|c|c|c|c|c|c|}
\hline \multirow[b]{2}{*}{ Characteristics } & \multicolumn{7}{|l|}{ Treatment } \\
\hline & $\mathrm{TR} 1$ & TR2 & TR3 & TR4 & RSD & SEM & Significant level \\
\hline Volume (ml) & 0,74 & 0,8 & 1,2 & 1,15 & 0,24 & 0,12 & $*$ \\
\hline $\mathrm{pH}$ & 6,48 & 6,51 & 6,72 & 6,73 & 0,13 & 0,067 & $*$ \\
\hline Color & Creme & Creme & Creme & creme & - & - & - \\
\hline Odor & Typical & Typical & Typical & Typical & & - & - \\
\hline Consistency & Medium Thick & Medium Thick & Thick & Thick & - & - & - \\
\hline
\end{tabular}

Information: (TR1) Local forage-concentrated content of 4\% PK without supplementation of zinc-biocomplex and vitamin $\mathrm{E}$

(TR2) TR1 + supplementation $60 \mathrm{mg}$ zinc $\mathrm{lkg}$ as zinc-biocomplex and vitamin $\mathrm{E}$

(TR3) TR1 + supplementation $120 \mathrm{mg}$ zinc $\mathrm{lkg}$ as zinc-biocomplex and vitamin $\mathrm{E}$

(TR4) TR1 + supplementation $180 \mathrm{mg}$ zinc lkg as zinc-biocomplex and vitamin E

$\mathrm{SEM}=$ Standar Error of the Means, RSD = Residuals Standard Deviation

NS $=$ No significant correlation, $*=\mathrm{P}<0,05$

Table 3: The quality of local kacang goat spermatozoa fed with zinc-biocomplex and vitamin E supplementation

\begin{tabular}{|c|c|c|c|c|c|c|c|}
\hline \multirow[b]{2}{*}{ Variable } & \multicolumn{7}{|c|}{ Treatment } \\
\hline & TR1 & TR2 & TR3 & TR4 & RSD & SEM & Significant Level \\
\hline Motillity (\%) & 73,03 & 75,12 & 80,46 & 78,17 & 3,28 & 1,64 & $*$ \\
\hline Viability (\%) & 78,62 & 79,82 & 81,76 & 80,53 & 1,31 & 0,657 & $*$ \\
\hline Concentration of spermatozoa $/ \mathrm{ml}$ & 3456 & 3587 & 3620 & 3606 & 75,39 & 37,695 & $*$ \\
\hline Live of spermatozoa (\%) & 97,5 & 98 & 98,3 & 98,2 & 0,38 & 0,18 & NS \\
\hline Abnormality of spermatozoa (\%) & 2,5 & 2 & 1,7 & 1,8 & 0,36 & 0,17 & NS \\
\hline
\end{tabular}

Information: (TR1) local forage-concentrated content of 4\% PK without supplementation of Zn-biocomplex and vitamin $\mathrm{E}$

(TR2) TR1 + supplementation + $60 \mathrm{mg}$ zinc lkg as Zinc-biocomplex and vitamin E

(TR3) TR1 + supplementation $120 \mathrm{mg}$ zinc lkg as Zinc-biocomplex and vitamin E

(TR4) TR1 + supplementation $180 \mathrm{mg}$ zinc $\mathrm{lkg}$ as Zinc-biocomplex and vitamin E

$\mathrm{SEM}=$ Standar Error of the Means, RSD = Residuals Standard Deviation

$\mathrm{NS}=$ No significant correlation, $*=P<0,05$

Tabel 3. shows that the storage time has a significant effect $(P<0.05)$ on the motility and viability percentages of spermatozoa in Kacang goats supplemented with $\mathrm{Zn}$ biocomplex and vitamin E. At 0,2 and 4 to $12 \mathrm{~h}$, the spermatozoa motility was found to still be within the minimum range for the Artificial Insemination (IA) program, which ranges from $54-75 \%$. However, there is a decrease along with the storage time up to $24 \mathrm{~h}$. According to research, the influence of feed consumed by livestock maintains the percentage of spermatozoa motility, with a significant decrease in TR1 treatment due to the absence of zinc biocomplex and vitamin $\mathrm{E}$ supplements. Conversely, the treatment of TR2, TR3 and TR4 still showed a fairly high percentage because the feed consumed by livestock was supplemented with zinc biocomplex up to $180 \mathrm{mg} / \mathrm{head}$ and vitamin $\mathrm{E}$. Therefore, it has the ability to maintain motility of spermatozoa for a longer period. Studies show that zinc is able to inhibit free radicals that damage spermatozoa. This is in line with the research carried out by Yulnawati (2005), which stated that zinc has antioxidant properties capable of inhibiting the occurrence of free radicals which damages spermatozoa during storage.
In addition, there was no significant difference $(P<0.05)$ in the storage time of goat spermatozoa viability, with an inter treatments decrease along the storage time from $0,2,4,6$ to $24 \mathrm{~h}$. At $12 \mathrm{~h}$, there was a significant decrease in TR1 (control) treatment caused by membrane damage that disturbed ATP synthesis with a decrease in viability. This is in line with Suharyati and Hartono (2013) research, which states that when membrane damage occurs, the ATP synthesis process fails to function properly, causing a decrease in viability during storage.

\section{Conclusion}

Supplementation of zinc-biocomplex and vitamin E to the feeding process had the potential to improve the quality of spermatozoa.

\section{Acknowledgement}

The authors thank to South Kalimantan Goat Farmers for their kind cooperation and assistance in spermatozoa sampling. 


\section{Funding Information}

The research was supported by the DRPM of Ristekdikti, Republic of Indonesia for funding this research through PTUPT grant and Islamic University of Kalimantan.

\section{Author's Contributions}

Tintin Rostini: Contributed on the original ideas of the research, data collection, analysis and interpretation and manuscript writing.

Danang Biyatmoko: Contributed on the original ideas of the research, data collection and manuscript preparation.

Irwan Zakir: Contributed input, data collection and analysis, laboratory and field work.

\section{Ethics}

This article is original and all of the other authors have approved and read the manuscript. The corresponding author confirm that no ethical issues involved.

\section{References}

Anerao, A.M., R.C. Sharma, R. Mansee and A.K. Gangawane, 2010. Studies on human sperm motility and viability when treatment with rock salt (Saindhav). J. Pathol. Res., 1: 1-10.

Bhardwai, J.K., P. Kumari, P. Saraf and A.S. Yadav, 2018. Antiapoptotic effects of vitamins $C$ and $E$ against cypermethrin-induced oxidative stress and spermatogonial germ cell apoptosis. J. Biochem. Mol. Toxicol., 32: 87-95. DOI: 10.1002/jbt.22174

Chenoweth, P.J., 2005. Genetic sperm defect. Heriogenology, 64: 457-468.

DOI: $10.1016 /$ j.theriogenology.2005.05.005

Dorado, J., I. Rodriguez and M. Hidalgo, 2007. Cryopreservation of goat spermatozoa: Comparison of two freezing extenders based on post-thaw sperm quality and fertility rates after artificial insemination. Theriogenology, 68: 168-177. DOI: $10.1016 /$ j.theriogenology.2007.04.048

Ebisch, I.M., W.I. Van Heerde, C.M. Thomas, N.N. Van Der Put and W.Y. Wong et al., 2003. C677T Methylene tetrahydrofolate reductase polymorphism interferes with the effects of folic acid and zinc sulfate on sperm concentration. Fertil. Steril., 80: 1190-1194. DOI: 10.1016/S0015-0282(03)02157-5

Elzananty, S. and J. Malm, 2007. Effects of ejaculation-to-analysis delay on levels of markers of epididymal and accessory sex gland functions and sperm motility. J. Androl., 28: 847-852.

DOI: $10.2164 /$ jandrol.107.002659
Hastono, T.C. and T. Herawati, 2013. Penampilan reproduksi ternak kerbau di Pande-glang (Reproductive performance of buffalo in Pandeglang). Proseding Seminar Nasional Teknologi Peternakan dan Veteriner.

Hidayati, H., 2017. Imbuhan pentoxifylline dalam pengencer tris kuning telur dan omega-3 dalam pengecer skim untuk meningkatkan kualitas semen beku kambing sapera Tesis. Program Studi Biologi Reproduksi. Institut Pertanian Bogor.

Inonie, M., I. La Ode Baa and T. Saili, 2016. Kualitas spermatozoa kambing boerawa dan kambing kacang pada penggunaan tris-kuning telur yang berbeda. JITRO, 3: 52-64.

Jeyendran, R.S., H.H. Vander-Ven, M. Perez-Pelaez, B.G. Crabo and L.J.D. Zanevld, 1984. Development of an assay to assess the functional integrity of the human sperm membrane and its relationship to other semen characters. J. Reprod. Fertil., 70: 219-228. DOI: 10.1530/jrf.0.0700219

Kartasudjana, R., 2001. Teknik inseminasi buatan pada ternak. Jakarta.

Kendall, N.R., S. McMullen, A. Green and R.G. Rodway, 2000. The effect of a zinc, cobalt and selenium soluble glass bolus on traceelement status and semen quality of ram lambs. Anim. Reprod. Sci., 62: 277-283. DOI: $10.1016 / \mathrm{S} 0378-4320(00) 00120-2$

Kusumawati, E.D., H. Leondro and A.T.N. Krisnaningsih, 2016. Pengaruh suhu dan lama simpan semen segar terhadap motilitas dan abnormalitas spermatozoa kambing Pernakan Etawah (PE). Seminar Nasional Hasil Penelitian.

Kusumawati, E.D., K.N. Utomo, A.T.N. Krisnaningsih and S. Rahadi, 2017. Kualitas semen kambing kacang dengan lama simpan yang berbeda pada suhu ruang menggunakan pengencer Tris aminomethan kuning telur. JITRO, 14: 42-50.

Lodhi, L.A., M. Zubair, Z.I. Qureshi, I. Ahmad and H. Jamil, 2008. Correlation between hypo-osmotic swelling test and various conventional semen evaluation parameters in fresh Nili-Ravi buffalo and Sahiwal cow bull semen. Pak. Vet. J., 28: 186-188.

NRC, 2007. Nutrient Requirement of Small Ruminants. 6th Edn. Washington DC, National Academy Press, USA.

Ogbuewu, I.P., N.O. Aladi, I.F. Etuk, M.N. Opara and M.C. Uchegbu et al., 2010. Relevance of oxygen free radicals and antioxidants in sperm production and function. Res. J. Vet. Sci., 3: 134-138. DOI: $10.3923 /$ rjvs.2010.138.164

Pamungkas, F.A. and B.A. Anwar, 2014. Cryopreservation of Boer goat spermatozoa: Comparison of two freezing extenders based on post-thaw sperm quality and fertility rates. JITV, 19: 130-137. 
Ridwan, 2009. Pengaruh pengencer semen terhadap abnormalitas dan daya tahan hidup spermatozoa kambing lokal pada penyimpanan suhu $5^{\circ} \mathrm{C}$. J. Agroland, 16: 187-192.

Salomon, S. and W.M.C. Maxwell, 2000. Storage of ram semen. Anim. Reprod. Sci., 62: 77-111. DOI: $10.1016 / \mathrm{S} 0378-4320(00) 00155-\mathrm{X}$

Simmon, L.W. and J.L. Fitzpatrick, 2012. Sperm wars and the evolution of male fertility. Reproduction, 144: 519-534. DOI: 10.1530/REP-12-0285

Smith, O.B. and O.O. Akinbamijo, 2000. Micronutrients and reproduction in farm animals. Anim. Reprod. Sci., 60: 549-560.

DOI: $10.1126 /$ science.287.5453.549c

Suharyati, S. and M. Hartono, 2013. Peningkatan kualitas semen kambing Boer dengan pemberian Vitamin E dan Mineral Zn. J. Kedokteran Hewan., 7: 91-93. DOI: 10.21157/j.ked.hewan.v7i2.897
Susilawati, T., 2011. Spermatologi. Universitas Brawijaya Press, Malang.

Wong, W.Y., H.M. Merkus, C.M. Thomas, R. Menkveld and G.A. Zielthuis et al., 2002. Effect of folic acid and zinc sulphate on male factor subfertility, a double blind, randomized placed controlled trial. Fertil. Steril., 77: 491-498. DOI: $10.1016 / \mathrm{S} 0015-0282(01) 03229-0$

Wroblewski, N., W.B. Schill and R. Henkel, 2003. Metal chelators change the human sperms motility pattern. Fertil. Steril., 79: 1584-1589. DOI: $10.1016 / \mathrm{S} 0015-0282(03) 00255-3$

Yulnawati, S.MA., 2005. Motilitas dan keutuhan membran plasma spermatozoa epididymis kucing selama penyimpanan pada suhu $4^{\circ} \mathrm{C}$. Med. Vet. J., 21: $100-104$

Zubair, M., 2017. Effects of dietary vitamin E on male reproductive system. Asian. Pac. J. Reprod, 6: 145-150. DOI: 10.12980/apjr.6.20170401 